Int. J. Morphol.,

28(2):375-378, 2010

\title{
Dens evaginatus in Hemophilic Patient. A Case Report
}

\author{
Dens Evaginatus en un Paciente Hemofílico. Reporte de un Caso \\ Eduardo Borie E.; Gonzalo Oporto V. \& Daniel Aracena R.
}

BORIE, E. E.; OPORTO, V. G. \& ARACENA, R. D. Dens evaginatus in hemophilic patient. A case report. Int. J. Morphol., 28(2):375$378,2010$.

SUMMARY: Tooth development occurs through the interaction between oral tissues during embryogenesis. Alteration through odontogenesis may cause tooth morphological alterations, one of these could be Dens evaginatus. This anatomical variation could be originated from an abnormal proliferation and folding of a portion of the inner enamel epithelium and subjacent ectomesenchymal cells of the dental papilla into the stellate reticulum of the enamel organ during the bell stage of tooth formation. Dens evaginatus is defined as a tubercle, or supplemental solid elevation on some portion of the crown surface. Inadequate clinical management of these teeth may result in a pulpal exposure and possible loss of vitality of the tooth. The research wants to report a case of Dens evaginatus in a permanent mandibular premolar requiring endodontic treatment. A 13-year old male patient attended the Dental Service of a local Hospital, reporting pain the lower left side of the jaw. He reported to be in medical treatment for hemophilia. During an intra oral examination, the left side in the mandible exhibited a multitubercular appearance of left premolars which suggest. Patient shows a sinus tract related to tooth 3,4 , which was sore to palpation and percussion. In radiographic analysis a radio-opacity appeared in the tubercle area of the tooth. Due to low incidence of this anomaly among the young population, it is important that Dentistry related professionals know the characteristics of this anatomical variation in order to perform an adequate clinical management of Dens evaginatus.

\section{KEY WORDS: Dental morphology; Dens evaginatus; Odontogenesis; Hemophilia.}

\section{INTRODUCTION}

Tooth development results of several interactions between oral epithelium and underlying mesenchymatic tissue during odontogenesis (Fuentes \& Oporto, 2009). Dental anomalies can results from many factors, including genetic and environmental ones. Although defects in certain genes have the higgest incidence, etiological events in the prenatal and postnatal periods have also been blamed for anomalies in tooth dimension, morphology, position, number, and structure (Uslu et al., 2009; Basdra et al., 2000).

Dens evaginatus is thought be originated from an abnormal proliferation and folding of inner portion of enamel epithelium and subjacent ectomesenchymal cells of the dental papilla into the stellate reticulum of the enamel organ during the bell stage of tooth formation. The resultant formation is defined as a tubercle, or supplemental solid elevation on some portion of the crown surface (Levitan \& Himel, 2006; Ngeow \& Chai, 1998).

In the literature, Dens evaginatus is defined as an uncommon developmental aberration of a tooth resulting in the formation of a supernumerary tubercle that extends from the occlusal aspect of an otherwise normal tooth (Uslu et al.).

The anomaly manifests itself as an innocuous-looking tubercle of enamel on the occlusal surface of a premolar tooth. Problems can arise when the tubercle is worn, ground, or fractured off, resulting in pulpal exposure and possible loss of vitality of the tooth. By malocclusions Orthodontists should be particularly aware of this dental anomaly, which occurs in at least $2 \%$ of the Asian and Native Indian individuals (McCulloch et al., 1997). This unusual condition occurs most frequently in Oriental people and is relatively uncommon in the western hemisphere population (Geist, 1989). The prevalence of Dens evaginatus reported on Chinese children and adolescents between 10-15 years of age was 6.3\% (Cho et al., 2006), and occurs more commonly in pre-molar teeth (Asgari et al., 2009).

The Dens evaginatus tubercles of posterior teeth average $2.0 \mathrm{~mm}$ in width, and up to $3.5 \mathrm{~mm}$ in length, as well as 
up to $3.5 \mathrm{~mm}$ in width and $6.0 \mathrm{~mm}$ in length for anterior teeth (Priddy et al., 1976; Levitan \& Himel). For the reason that Dens evaginatus tubercle may extend above the occlusal surface up to $3.5 \mathrm{~mm}(6.0 \mathrm{~mm}$ for anterior teeth), malocclusion with the opposing tooth upon the cusp-like elevation occurs as involved teeth erupt into the dental arches. The resultant occlusal traumatic force causes abnormal wear or fracture of tubercle, and is the usual manner of pulp exposure for this anomaly (Levitan \& Himel).

The aim of this case report is to describe a Dens evaginatus in a permanent mandibular premolar requiring endodontic treatment in a hemophilic patient.

\section{CASE REPORT}

A 13-year-old male patient attended to Dental Service of local Hospital reporting pain in the lower left side of the jaw. During anamnesis, patient reported suffering hemophilia, without another past history for systemic diseases. Likewise, patient related that nobody in his family has presented the same dental alteration (Dens evaginatus). Extra oral inspection did not reveal any kind of clinical alteration. At oral examination, the left side in mandible exhibited a hypoplasic canine and two similar morphologic anomalies in left premolars; such a multi tubercular appearance of which suggest Dens evaginatus (Figs. 1 and 2). Patient did not show malocclusion or strong premature contacts associated to Dens evaginatus. A sinus tract was found related to tooth 3.4. The tooth 3.4 was tender to palpation and percution. In radiographic analysis appeared a radio-opacity in tubercle zone of tooth 3.5 (Fig. 3).

Considering signs and symptoms detected, was indicated to perform an endodontic treatment to preserve teeth. This decision avoided a dental extraction, taking into account disease of patient (hemophilia) and absence of occlusal alterations caused by altered tooth.

\section{DISCUSSION}

Dens evaginatus is a developmental anomaly that produces a tubercle on the occlusal surface of a tooth. The patient had this dental anomaly in left mandibular premolars. This location has been reported as the most frequent position of Dens evaginatus (Chen et al., 2005). There is not relationship between hemophilia and Dens evaginatus explicitly in the literature; however it could be associated with odontogenesis process, because some authors postulate that dental anomalies can result from many factors, including genetic and environmental ones (Uslu et al.; Basdra et al.).

This is such an important case report at local scale because Dens evaginatus has been scarcely reported, and also for the subsequent potential pulpar problems to the patients derived from this anomaly. Due to low incidence of

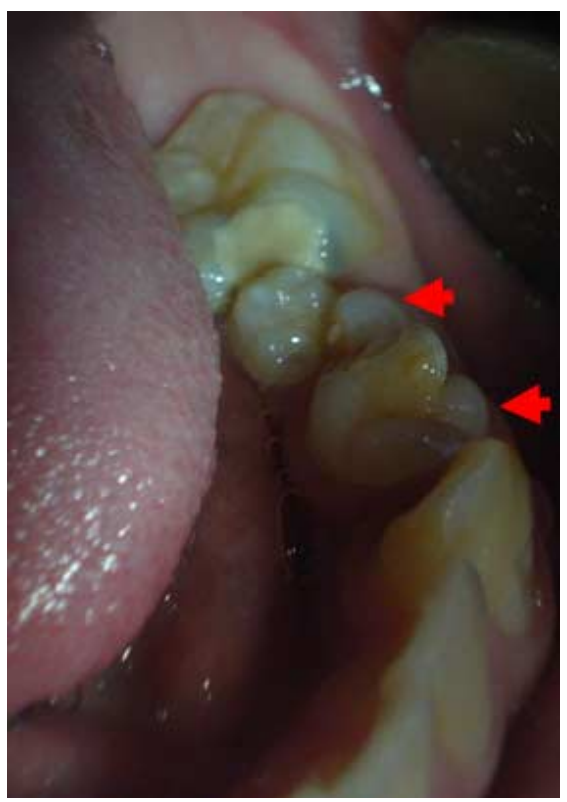

Fig. 1. Intra oral occlusal view of Dens evaginatus (arrows).

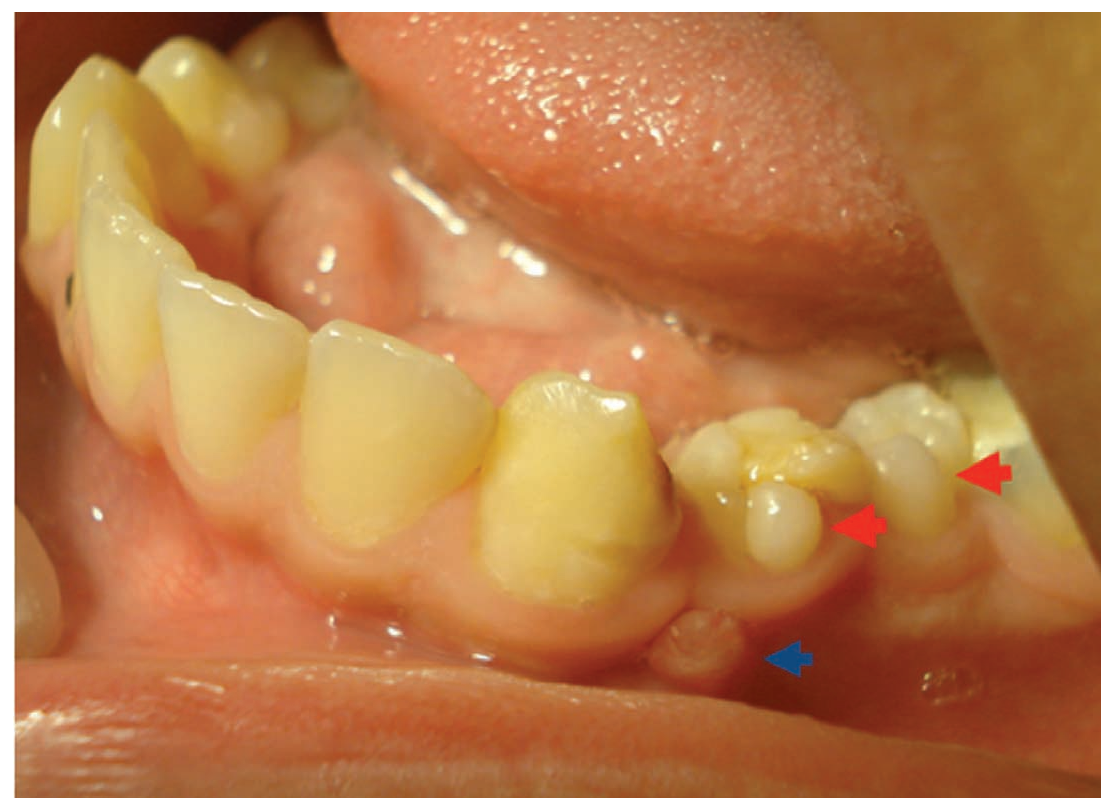

Fig. 2. Left side view of mandible. Teeth 3.4 and 3.5 with Dens evaginatus (red arrows) and sinus tract (blue arrow). 


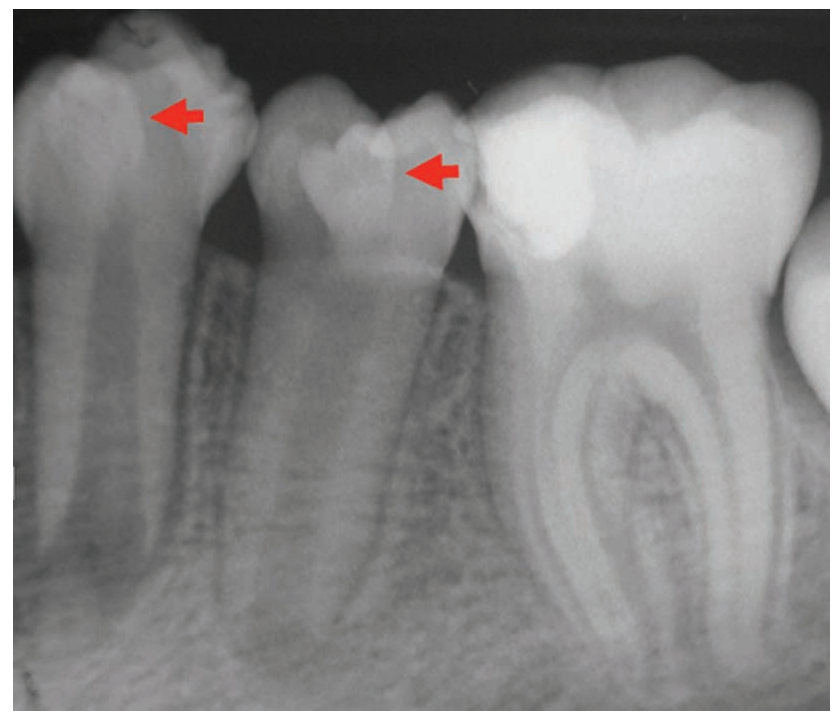

this dental anomaly among population, is important that Dentistry area professionals must well known about this anatomical variation, as well as must be prepared to perform a carefully treatment planning previously to intervene a Dens evaginatus, to avoid unexpected problems during dental treatments procedures generated by ignorance of morphology of this anatomical variation.

Fig. 3. Radiographic view of Teeth 3.4 and 3.5.

Arrows show Dens evaginatus.

BORIE, E. E.; OPORTO, V. G. \& ARACENA, R. D. Dens evaginatus en un paciente hemofílico. Reporte de un caso. Int. J. Morphol., 28(2):375-378, 2010.

RESUMEN: El desarrollo dentario se produce por la interacción de tejidos orales durante la embriogénesis. Alteraciones en la odontogénesis pueden causar alteraciones morfológicas, una de ellas es Dens evaginatus. Esta variación anatómica se puede originar de la proliferación anormal de la porción interna del epitelio del órgano del esmalte y las células ectomesenquimáticas del retículo estrellado durante el estado de campana de la odontogénesis. La resultante puede ser una estructura definida como una elevación sólida suplementaria de la corona dentaria. Un manejo clínico inadecuado de dientes con esta alteración puede resultar en una exposición pulpar y posible pérdida de la vitalidad del diente. La investigación reporta el caso clínico de un paciente hemofílico con un Dens evaginatus que requiere tratamiento de endodoncia. Un paciente de 13 años de edad de sexo masculino consultó en el servicio dental del Hospital local en la zona izquierda de la mandíbula. Al examen intraoral presentó premolares mandibulares izquierdos con apariencia multitubercular compatibles con Dens evaginatus. Se observó una fístula en relación al diente 3.4, el que se encontraba sensible a la percusión y palpación. El análisis radiográfico reportó una zona radiopaca en relación a la zona tubercular del diente. En consideración a la baja incidencia de esta variación anatómica, es importante para los profesionales del área de la Odontología conocer las características del Dens evaginatus, con el ánimo de lograr un adecuado abordaje clínico al momento de tratar dientes con esta alteración morfológica.

PALABRAS CLAVE: Morfología dentaria; Dens evaginatus; Odontogénesis; Hemofilia.

\section{REFERENCES}

Asgari, A.; Kaufman, E.; Kourtsounis, P. \& Baharestani, M. Apexification of non-vital pre-molar stemming from possible Dens evaginatus. N. Y. State Dent. J., 75(2):346, 2009.

Basdra, E. K.; M. Kiokpasoglou, M. \& Stellzig, A. The Class II Division 2 craniofacial type is associated with numerous congenital tooth anomalies. Eur. J. Orthod., 22(5):529-35, 2000.

Chen, C.; Lee, K.; Chuang, F.; Hong, Y.; Chen, H.; Hsu, K; Wu, Y. \& Lee, H. Facial cellulitis arising from Dens evaginatus: A Case Report. Kaohsiung J. Med. Sci., 21(7):333-6, 2005.
Cho, S. Y.; Ki, Y.; Chu, V. \& Chan, J. Concomitant developmental dental anomalies in Chinese children with dens evaginatus. Int. J. Paediatr. Dent., 16(4):247-51, 2006.

Fuentes, R. \& Oporto, G. Ectopic and impacted third molar in retromolar zone. A Case Report. Int. J. Morphol., 27(1):35-8, 2009.

Geist, J. R. Dens evaginatus: Case report and review of the literature. Oral Surg. Oral Med. Oral Pathol. Oral Radiol. Endod., 67(5):628-31, 1989.

Levitan, M. \& Himel, V. Dens Evaginatus: Literature review, 
BORIE, E. E.; OPORTO, V. G. \& ARACENA, R. D. Dens evaginatus in hemophilic patient. A case report. Int. J. Morphol., 28(2):375-378, 2010.

pathophysiology, and comprehensive treatment regimen. J. Endod., 32:1-9, 2006.

McCulloch, K. J.; Mills, C. M.; Greenfeld, R. S. \& Coil, J. M. Dens evaginatus from an orthodontic perspective: Report of several clinical cases and review of the literature. Am. J. Orthod. Dentofac. Orthop., 112(6):666$9,1997$.

Ngeow, W. C. \& Chai, W. L. Dens evaginatus on a wisdom tooth: a diagnostic dilemma. Case report. Aust. Dent. J., 43(5):328-30, 1998.

Priddy, W. L.; Carter, H. G. \& Auzins, J. Dens evaginatusan anomaly of clinical significance. J. Endod., 2(2):512, 1976.

Uslu, O.; Akcam, M. O.; Evirgen, S. \& Cebeci, I. Prevalence of dental anomalies in various malocclusions. Am. J. Orthod. Dentofacial. Orthop., 135(3):328-35, 2009.
Correspondence to:
Gonzalo Oporto V.

Departamento de Odontología Integral

Facultad de Medicina

Universidad de La Frontera

Manuel Montt 112

Temuco - Chile

Phone: 56-45-325775.

Email: goporto@ufro.cl

Received: 30-07-2009

Accepted: 16-02-2010 